\title{
LA ETERNIDAD DEL MUNDO EN BOECIO \\ DE DACIA Y EN SANTO TOMÁS DE AQUINO
}

\section{THE ETERNITY OF THE WORLD IN BOETHIUS OF DACIA AND SAINT THOMAS AQUINAS}

\author{
EUDALDO FORMENT" \\ Universidad de Barcelona
}

Resumen: En la cristiandad medieval, a pesar del dogma del comienzo temporal del mundo, confirmado por la tradición patrística, se discutió si es concebible un mundo eterno. Boecio de Dacia, en su Tratado de la eternidad del mundo, afirmaba que la Filosofía de la Naturaleza debe rechazar que el mundo tuviera un comienzo temporal, y sustentar que la creación no es posible, aunque lo contrario de las dos tesis debe mantenerse por la fe. En la Facultad de Teología de la Universidad de París, en cambio, se enseñaba que no es posible que el mundo haya sido creado desde la eternidad, porque racionalmente se prueba que es temporal, tal como se lee en la Biblia. Frente a estas dos posiciones opuestas, Santo Tomás, en La eternidad del mundo, sostiene que creación y eternidad no repugnan entre sí, pero que no se puede demostrar la eternidad del mundo, ni tampoco su temporalidad. Si el mundo ha existido siempre o comenzó en algún momento temporal no tiene respuesta para la filosofía, pero desde la fe se cierra la cuestión. El examen detenido de la confrontación de estas tres posiciones en la polémica parece revelar que dependen, en último término, de las tres diferentes soluciones que dan al problema de la razón y la fe.

Palabras claves: Boecio de Dacia, Santo Tomás de Aquino, San Buenaventura, San Agustín, eternidad, temporalidad, creación, verdad, fe y razón.

Aвstract: In medieval Christianity, despite the dogma of the temporal beginning of the world, confirmed by the Patristic tradition, the issue of whether an eternal world is conceivable was discussed. Boethius of Dacia, in his treatise On the Eternity of the World, stated that the Philosophy of Nature must reject a temporal beginning of the world and sustain that creation is not possible, though the opposite of these two theses

\footnotetext{
*Email: eforment@ub.es.
} 
must be maintained by faith. In the Faculty of Theology at the University of Paris, however, it was taught that it is not possible for the world to have been created from eternity, because, rationally, it is proven to be temporary, as we read in the Bible. In contrast to these two opposite positions, Saint Thomas, in The Eternity of the World, states that creation and eternity do not reject one another, but that neither the eternity of the world nor its temporality, can be proven. Whether the world has always existed or began in a temporal moment, has no philosophical answer; notwithstanding, the issue is solved through faith. An accurate examination of the controversy regarding these three positions seems to reveal that, ultimately, they depend on the three different solutions given to the problem of reason and faith.

Keywords: Boethius of Dacia, Saint Thomas Aquinas, Saint Bonaventure, Saint Augustine, eternity, temporalness, creation, truth, faith and reason.

\section{Creación temporal}

En su opúsculo La eternidad del mundo, escrito en 1270 y ya al final de su vida, comienza Santo Tomás con la presentación de un problema: «Supuesto según la fe católica, que el mundo tuvo un comienzo en el tiempo, se ha suscitado la duda de si ha podido existir desde siempre» ${ }^{1}$.

En la fe de la Iglesia se afirma que el mundo fue creado por Dios en el tiempo. Es un dato revelado que la creación fue en el tiempo y, por tanto, tuvo un comienzo temporal. Se dice ya en las primeras palabras de la Biblia, del Antiguo Testamento: "Al principio creó Dios el cielo y la tierra» (Gén 1,1). Más adelante, al hablar de la sabiduría de Dios, se afirma: «En un tiempo remoto fui formada, antes de que la tierra existiera» (Prov 8, 23). También en un salmo se lee: «Antes que naciesen los montes o fuera engendrado el orbe de la tierra desde siempre y por siempre tú eres Dios» (Sal 90, 2). Algo parecido se encuentra en otro: «Al principio cimentaste la tierra, y el cielo es obra de tus manos» (Sal 101, 26).

En el Nuevo Testamento, el mismo Cristo, en el denominado Sermón de la Cena dice: «Y ahora, Padre, glorifícame junto a ti, con la gloria que yo tenía junto a ti antes que el mundo existiese» (Jn 17, 5); y un poco más adelante: «Padre, este es mi deseo: que los que me has dado estén conmigo donde yo estoy y contemplen mi gloria, la que me diste, porque me amabas, antes de la fundación del mundo» (Jn 17, 24). También San Pablo, en una de sus cartas escribe: «El

\footnotetext{
1 Santo Tomás de Aquino (1953). Véase también Michon (2004), pp. 145 s.
} 
nos eligió en Cristo antes de la fundación del mundo, para que fuésemos santos e intachables ante él por el amor» $(\mathrm{Ef} 1,4)$.

Ante estos testimonios, claros y rotundos, de que el mundo alguna vez no existió, y que después comenzó a existir, la Iglesia, precisamente en la Edad Medía, declaró como dogma de fe el comienzo temporal del mundo. En el IV Concilio de Letrán, en 1215, en el decreto Firmiter, se comienza afirmando: «Firmemente creemos y simplemente confesamos, que uno solo es el verdadero Dios (...) creador de todas las cosas, de las visibles y de las invisibles, espirituales y corporales; que por su omnipotente virtud a la vez desde el principio del tiempo creó de la nada a una y otra criatura, la espiritual y la corporal, es decir, la angélica y la mundana, y después la humana, como común, compuesta de espíritu y de cuerpo» (Dz 428). El mismo Santo Tomás comentó este documento conciliar en la Exposición de la primera y segunda Decretal, escrito unos pocos ańos antes del opúsculo sobre la eternidad del mundo, a petición de un amigo suyo arcediano de Todi $^{2}$.

También Santo Tomás conoció las tesis del carácter temporal del mundo de los padres de la Iglesia, que mantuvieron frente a las posiciones de la filosofía pagana de la eternidad del mundo o, mejor dicho, de la eternidad de la materia cósmica. Únicamente Orígenes, en el primer tercio del siglo III, consideró la creación de Dios como un acto eterno. Afirmó la existencia de un mundo anterior al actual, un mundo de espíritus perfectos, parte de los cuales decayeron y quedaron relegados en la materia creada posteriormente ${ }^{3}$. El primer mundo fue creado por Dios desde toda la eternidad, porque no serían posibles la omnipotencia y la bondad de Dios sin que se manifestasen en algún objeto. Sería, por tanto, «impío y a la vez absurdo, pensar que la bondad alguna vez no hizo el bien, o la omnipotencia alguna vez no realizara su poder ${ }^{4}$. Con ello, quedaba conciliada la temporalidad de la creación, que mantiene la Sagrada Escritura, con la tesis platónica de la eternidad del mundo.

2 Pocos años después, ya fallecido Santo Tomás, el papa Juan XXII condenó como «heréticas» (Denzinger (1963) [en lo sucesivo Dz] 529) varias proposiciones sacadas de la obras del Maestro Eckhart, entre ellas, las siguientes: «Puede concederse que el mundo fue ab aeterno» (Dz 502) y «Juntamente y de una vez, cuando Dios fue, cuando engendró a su Hijo Dios, coeterno y coigual consigo en todo, creó también el mundo» (Dz 503).

3 Orígenes, De principiis, III, 5, 3; en Migne (1857), Patrologia Graeca [en lo sucesivo PG] 11, col. 111-412.

${ }^{4}$ Ibíd., III, 5. 
En cambio, Taciano el sirio, del siglo II, discípulo de San Justino, escribió: «La materia no está sin principio, como Dios, ni tiene un poder igual al de Dios siendo sin principio, sino que ha sido creada. Y no por otro ha sido creada fuera del que la produjo como creador de todas las cosas» ${ }^{5}$.

Igualmente en el siglo II, San Ireneo de Lyon, en su conocida obra Contra los herejes, declaraba: «El Señor de todas las cosas, no tiene principio ni fin, y es el único que permanece siendo el mismo para siempre. Todas las cosas que de él provienen, que ha creado y sigue creando, tienen un principio y generación, y por ese motivo son inferiores a aquel que las ha hecho, porque no son increadas; sino que duran y permanecen en el tiempo según la voluntad del Dios Creador: así como al principio les concede comenzar a existir, así después les concede el ser ${ }^{6}$.

San Basilio Magno, el monje obispo de Cesarea de Capadocia, en el siglo IV, autor que el Aquinate apreciaba y conocía muy bien, en sus homilías Acerca del Hexaemerón, enseñaba que el mundo visible comenzó a existir en el tiempo. «En el instante intemporal del querer divino, el mundo existió» ${ }^{7}$. Notaba que el movimiento circular de los astros no era una prueba de la eternidad del mundo. Por el contrario, era preciso que lo creado, que está sujeto siempre al movimiento y por tanto nace y muere, esté a su vez envuelto por el tiempo, cuya naturaleza también es la de comenzar y acabar ${ }^{8}$.

Además de enseñar la creencia, basada en la Sagrada Escritura y en el magisterio de la Iglesia, en la Patrística se sostuvo que no es posible concebir racionalmente una criatura eterna. La creación no fue en la eternidad porque no se puede dar un ser creado que sea eterno. Todos rechazaron la doctrina de Orígenes. Por ejemplo, San Atanasio de Alejandría, doctor de la Iglesia, en el siglo IV, escribía: "Aunque Dios puede crear siempre, las cosas creadas no pueden ser eternas; pues fueron hechas de la nada y, por tanto, no fueron antes de ser»?

\footnotetext{
5 Taciano, Oratio ad Graecos, 5; en PG 3, col. 803-888.

6 San Ireneo. Adversus haereses, II 34, 2, en PG 7, 7b, col. 433-1222.

7 San Basilio Magno, Homiliae in Hexaemeron, hom. I, 5 E; en PG 29b, col. 1-206.

8 Ibíd., 7 B.

9 San Atanasio, Orationes contra arianos, disc. I, 29; en PG 26, col. 9-524.
} 


\section{Eternidad del mundo}

A pesar del dogma del comienzo temporal del mundo, confirmado por la tradición patrística, en la cristiandad medieval, en el siglo XIII, se discutió si es concebible un mundo sin principio temporal, un mundo eterno. Se inició la polémica con la corriente filosófica llamada averroísmo latino o aristotelismo radical. Por ello, continua escribiendo Santo Tomás en La eternidad del mundo: «Se ha suscitado la duda de si ha podido existir [el mundo] desde siempre» ${ }^{10}$.

Uno de los primeros biógrafos de Santo Tomás, Guillermo de Tocco, nacido en la mitad del siglo XIII, alumno de Santo Tomás y que vivió en la misma comunidad de Nápoles, y preparó una exposición de su vida en el proceso de canonización en 1318, en su Ystoria sancti Thome de Aquino ${ }^{11}$ explica así la oposición del Aquinate a las tesis averroístas: "Refutó a herejes y también a otros doctores de algunas de las nuevas herejías, que aparecieron durante su época, sirviéndose de la revelación del Espíritu divino. La primera de estas herejías fue la contenida en el error de Averroes, que dijo que sólo existe una única inteligencia para todos los hombres. Este error favorecía los errores de los impíos y ocasionaba un grave perjuicio a las virtudes de los santos, porque si sólo hubiese una única inteligencia para todos los hombres, no existiría entre ellos ninguna diferencia, y sus méritos serían los mismos».

Esta doctrina sobre el entendimiento, a diferencia de la segunda — que sería la doctrina antimendicante de Guillermo de Saint-Amour y sus seguidores-, fue muy popular. Según Tocco: «El error contó con mucha reputación entre la gente, incluso entre los más sencillos. Penetró de un modo tan peligroso, que un soldado en París, a quien se le preguntó si quería, en sus últimos momentos de su vida, purificar sus crímenes, respondió: "Si el alma del bienaventurado Pedro se ha salvado, yo también quedaré salvado, pues si no tenemos más que una sola inteligencia para conocer, nuestro final también será el mismo"».

En la universidad, la doctrina de la unidad del intelecto tenía su lugar propio y desde allí se había ido difundiendo. Para algunos historiadores actuales los averroístas fueron sólo una minoría universitaria y no parece que su influencia trascendiera eficazmente al pueblo. En cambio, según Tocco, el averroísmo tuvo éxito entre profesores y estudiantes e incluso fuera del mundo universitario, de

10 Santo Tomás de Aquino (1953), p. 295.

11 Le Brun-Gouanvic (1996). 
manera que: «Este error se ganó un gran número de discípulos, entre ellos los estudiantes goliardos, pues las razones con las que se les convencía eran sofísticas. Contra ellas compuso también santo Tomás un escrito admirable. Con argumentos obtenidos de la fe, con esta obra acabó con este error. Asimismo, en este mismo libro acudió al texto de Aristóteles, porque había sido mal entendido e interpretado por Averroes. Pudo así extirpar el error en sus raíces y demostrar así que no tiene ninguna razón, de manera que no haya persona alguna capaz de leer los textos de Aristóteles y que dude de que este error sea irracional» ${ }^{12}$.

Los llamados averroístas o "aristotélicos radicales», profesores en la Facultad de Artes de París, que explicaban las obras de Aristóteles y la mayoría interpretándolo según el molde de Averroes, querían separar la filosofía aristotélica de toda relación con la religión. Se proclamaban, no obstante, creyentes. Además, al enseñar doctrinas que contradecían la fe cristiana, como la eternidad del mundo, no la presentaban como absolutamente verdadera, sino como una conclusión racional o filosófica. De ahí que los profesores de la Facultad de Teología les acusaran de enseñar una doble verdad, una valida para la filosofía y otra para la Teología. Se defendían negando que aceptaran esta absurda doctrina, sino que ellos como filósofos se limitaban a investigar las enseñazas de los filósofos o bien decían que las conclusiones filosóficas no eran necesarias, sino probables. En realidad, como Gilson ha indicado de Boecio de Dacia, se puede decir del averroísmo que «no sólo hace abstracción de la fe cristiana; además, no se advierte que se sienta desgraciado lejos de ella» ${ }^{13}$.

Los teólogos, que no podían concebir que la razón llevase a tesis que se opusieran a la verdad revelada, temían que la posición del movimiento averroísta llevara a afirmar que la razón tenía una supremacía sobre la fe, y que esta quedase finalmente como falsa. En 1270 eran tan enconadas las disputas que el obispo de la diócesis, Esteban Tempier, se creyó obligado, para evitar los peligros que entrañaban para la fe de sus fieles, a decretar la condenación formal de trece proposiciones sostenidas por los filósofos de la Facultad de Artes de la Universidad de París. Entre las proposiciones condenadas, en el decreto de fecha 10 de diciembre de 1270, la quinta era la siguiente: «Que el mundo es eterno» ${ }^{14}$.

12 Ferrua (1968).

13 GiLson (1965), p. 527.

14 Denifle-Chatelain (1964), t. 1, n. 432, 486-487, «Tredecem errores a Stephan episcopo Parisiensi condemnati. 1270, 10 de Decembris, Parisiis»). «Estos son los errores condenados por el señor Esteban, obispo de París, en el año del Señor 1270, en el día miércoles después de la fiesta del beato Nicolás de invierno, y serán excomulgados todos aquello que al conocerlos los 
La condenación no terminó con el averroísmo. En 1277, a los tres años de la muerte de Santo Tomás, el obispo tuvo que volver a condenarlo ${ }^{15}$. Esta dramática lucha cultural entre las dos facultades de la Universidad de París, en la que intervino Santo Tomás, tuvo unas importantes consecuencias históricas, que muchas veces no se advierten. Por un lado, supuso una nueva forma de realizar las tareas filosóficas y teológicas. Por otro, con el averroísmo latino no sólo se inició la separación de la filosofía y la teología, sino también la evolución de la misma Facultad de Artes, que culminó en su transformación posterior en Facultad de Filosofía. Desde ella, continuó un enfrentamiento a la teología y a la fe, que fue progresando en el tiempo.

\section{Eternidad y temporalidad}

El autor más conocido en su misma época del averroísmo del siglo XIII fue Sigerio de Brabante, pero su nombre siempre aparecía unido al profesor sueco Boecio de Dacia, considerado también como otra de las cabezas de este movimiento de la Facultad de Artes parisina, y que durante alguna época fue dominico y, por ello, se le denominaba de Dacia, nombre de la provincia dominicana, que incluía Suecia y Dinamarca. Además, se consideró que las tesis condenadas por el obispo de París, en 1277, eran principalmente de Boecio. Incluso en uno de los manuscritos de la condenación así se indica. No es difícil averiguarlo, porque desde hace algunos años se van reconociendo obras suyas.

Entre las tesis condenadas en 1277, y que enseñaba Boecio, estaba que la Filosofía de la Naturaleza debe rechazar que el mundo tuvo un comienzo temporal, aunque con ello se contradiga la fe cristiana, y que la creación no es posible, aunque lo contrario hay que mantenerlo por la fe. Estas tesis, tal como las expone en su Tratado de la eternidad del mundo ${ }^{16}$ se apoyaban en el rechazo de un ideal

enseñen o sostengan. El primer artículo es que todos los hombres están dotados de uno y el mismo entendimiento; 2. Que es falso decir que el hombre comprende; 3. Que la voluntad del hombre no dispone de libre albedrío, sino que elige necesariamente; 4. Que todos los acontecimientos terrenales ocurren necesariamente, por el influjo de los cuerpos celestes; 5. Que el mundo es eterno; 6. Que nunca hubo un primer hombre; 7. Que el alma, que es la forma del cuerpo, se corrompe con él; 8. Que cuando el alma se separa del cuerpo, por las muerte, no puede sufrir los efectos del fuego corpóreo; 9. que el libre albedrío es una facultad pasiva y no activa, y que está determinado necesariamente por el objeto deseado; 10. Que Dios no conoce las cosas individuales; 11. Que Dios sólo se conoce a sí mismo; 12. Que Dios no ejerce providencia alguna sobre los actos humanos; 13. Que Dios no puede hacer inmortal a una criatura mortal».

15 Denifle-Chatelain (1964), t. 1 (1889), n.474, 543-555.

16 Boecio de Dacia (1964). Véase también la traducción en Michon (2004), pp. 178-214. 
de la cristiandad medieval: que la filosofía y, en general, la razón humana era el soporte o fundamento de la fe y que podía además defender la racionabilidad de la misma fe. Para Boecio, la razón y la fe estaban separadas. La razón humana no guardaba relación con la fe y, en este sentido, era autónoma. La filosofía debía ser independiente de lo enseñado por la fe.

La filosofía y la fe, por motivos metodológicos, deben estar totalmente separadas. La primera tiene por objeto el descubrimiento de los principios y las causas naturales del mundo, utilizando el entendimiento humano para una investigación racional. En cambio, la fe tiene por objeto lo revelado por Dios y por tanto se basa en la revelación divina, en su veracidad y en la confirmación de los milagros. Tienen, por tanto, diferentes sus orígenes, diferentes objetos y puntos de vista y, por ello, no coinciden en los mismos ámbitos.

Esta nueva actitud respecto a la filosofía y a la fe se advierte claramente en la cuestión de la eternidad del mundo. Por la fe, se sabe, por encima del ámbito natural y por encima de la razón, que el mundo no fue eterno, sino que fue creado por Dios y tuvo así un comienzo temporal. En cambio, por la filosofía, permaneciendo en el nivel de la misma naturaleza y por investigación racional, se conoce que todos los hechos de la naturaleza son efectos, que son el resultado de otros hechos naturales, que han actuado como causas. Se infiere, por ello, que el movimiento, y, además, consecuentemente el tiempo, no han tenido un inicio absoluto. En definitiva, que el mundo es eterno.

Esta conclusión, resultado de la investigación filosófica, utilizando el derecho de seguir los principios de la naturaleza hasta sus últimas consecuencias, es opuesta a la verdad de fe, que está más allá del alcance de la razón humana. Sin embargo, Boecio no cree que exista contradicción entre ambas, porque las conclusiones de la filosofía no son siempre necesarias, sino que son solamente probables, como en la afirmación de la eternidad del mundo. Este es el objetivo del Tratado de la eternidad del mundo, el mostrar que no hay desacuerdo sobre esta cuestión entre la filosofía y la fe.

La razón humana no puede demostrar la eternidad del mundo de manera necesaria. Por ello no tienen fuerza las razones que «los herejes (haeretici) aportan sobre la eternidad del mundo para tratar de impugnar la doctrina de la fe cristiana, que afirma que el mundo es nuevo» ${ }^{17}$.

17 Boecio de Dacia (1964). Cf. Michon (2004), pp. 145 s. 
Después de examinar las distintas razones a favor y en contra, Boecio establece que, en cambio, la Filosofía de la Naturaleza demuestra la eternidad del mundo, en su ámbito y en su modo. Por el contrario, ningún filosofo puede demostrar desde los principios de la naturaleza que el movimiento y el mundo hayan tenido un comienzo temporal.

Desde la naturaleza sólo se conoce el movimiento, y un movimiento que no es nuevo, sino que ha sido precedido por otro, que ha sido su causa. Tampoco puede haber cambio en un ser si no hay una "transmutación», ni, por ello, tampoco se puede partir de un "primer hombre», que tendría que ser inengendrado. No obstante, no se puede dudar que hubo un primer hombre y que el mundo fue creado, pero desde la Filosofía de la Naturaleza no se tiene derecho a salirse de su ámbito, a sobrepasar sus límites, ni para obtener verdades, que pertenecen a otra ciencias, ni para negarlas. Si, en cambio, puede y debe negar todo lo que contradice sus propios principios. Así, por ejemplo, se debe negar la resurrección de los muertos, que se opone a las causas naturales.

El filósofo de la naturaleza no puede decir que el mundo ha comenzado, si se permanece en el ámbito de los principios y causas naturales, pero en sentido absoluto no puede sostener que el mundo no ha comenzado. En este sentido ultimo, la Filosofía de la Naturaleza no puede pronunciarse.

Tampoco pueden hacerlo las Matemáticas, ya sea la geometría, ya la astronomía, porque tanto si el mundo fuese eterno como si hubiese sido creado, no quedarían afectados sus principios matemáticos, que continuarían siendo los mismos, y desde los que se parte para sus investigaciones. Ni asimismo a la Metafísica le compete demostrar la no eternidad o comienzo del mundo, porque afirma que el mundo depende de la voluntad divina, que no es cognoscible para la razón humana, y aunque Dios podía querer que fuese creado y que tuviese un comienzo en el tiempo, no es posible saberlo desde la ciencia metafísica.

Como la revelación enseña una verdad absoluta, que debe ser creída por fe, y la razón humana ha llegado por la razón a una conclusión contraria, pero sólo probable, cree Boecio que esta situación no lleva a la negación de la fe, es más: incluso afirma la reconciliación entre la razón y la fe. «Y como muchas de las cosas que pone la fe son de este modo, cosas que no pueden investigarse por la razón humana, por ello falta la razón, que suple su falta la fe, y que debe manifestar que el poder divino está por encima de la cognición humana. Ni, por esto, se deja de creer en los artículos de la fe, porque algunos de ellos no puedan ser 
demostrados, porque, si se procede así, no se sigue ninguna ley, porque no hay ninguna ley de la que todos los artículos puedan ser demostrados».

Concluye Boecio: «Así, se manifiesta que no hay ninguna contradicción entre la fe cristiana y la filosofía de la eternidad del mundo, si se examina atentamente lo dicho, así como también se manifestará, con la ayuda de Dios, en las restantes cuestiones, y se verá que la fe cristiana y la filosofía consideradas superficialmente $\mathrm{y}$ menos atentamente por el hombre parecen discordar ${ }^{18}$.

Podría pensarse que, por ser el ámbito de la fe el de la verdad absoluta, habría que renunciar a la verdad racional. Boecio lo niega. No cree que la Filosofía deba ceder o renunciar a su verdad frente a la Teología. Defiende apasionadamente el derecho de la filosofía a poder tratar todas las cuestiones que pertenezcan al campo de la razón humana. El transigir en este punto ante la Teología, aunque no lleve a la verdad absoluta, supondría nada menos que perder la libertad de la Filosofía.

Tal era la pretensión de teólogos de la Facultad de Teología, como San Buenaventura, que negaban el derecho de la Filosofía a estudiar la eternidad del mundo, y otros problemas difíciles, argumentando que llevaban a algo contrario a la fe, y, por tanto, al error. A Boecio, le parece que temían el conflicto entre la razón y la fe y este temor les llevaba a negar el derecho de la filosofía al estudio de todos los seres, naturales, matemáticos o trascendentes, hasta donde pudiera con la razón natural. Con ello destruían la Filosofía misma. Advierte ante esta posición que «los cristianos realmente inteligentes no se sienten obligados por su religión a destruir los principios de la filosofía, sino que conservan la fe y la filosofía sin atacar a la una ni a la otra» ${ }^{19}$.

Para ello, la Filosofía y la Teología deben mantenerse separadas. Cada una tiene su lugar y su influencia en la vida humana. Para evitar que exista conflicto entre ellas, hay que procurar que no se relacionen, porque no pueden tener ninguna conexión, ni mucho menos estar armonizadas, simplemente lo único pueden ambas es coexistir. Boecio no tiene en cuenta ya la doctrina agustiniana del «entiende para creer, cree para entender ${ }^{20}$. Estima que hay que esperar entre

\footnotetext{
18 Boecio de Dacia (1964). Cf. Michon (2004), p. 203.

19 Boecio de Dacia (1964). Cf. Michon (2004), p. 214.

20 San Agustín (1983), Sermo 43, Tractatus contra manichaeos de eo quod scriptum est: «In principio fecit Deus caelum et terram» (Gen 1,1) et "In principio erat Verbum»" (Io 1,1), p. 7.
} 
la fe y la razón tensiones y conflictos, porque llegan a conclusiones contrarias, pero porque sus fines y métodos son distintos. Sin embargo, para los teólogos de la Facultad de Teología, esta tesis implicaba que admitía la existencia de verdades contradictorias o la «doble verdad».

\section{El problema de la creación}

Para precisar la cuestión debatida, añade Santo Tomás, en el opúsculo La eternidad del mundo, lo que determinará su postura ante los filósofos de la Facultad de Artes y ante los teólogos de la Facultad de Teología. Escribe seguidamente en el mismo: «Para entender el sentido de esta duda hay que distinguir antes en que convenimos con nuestros opositores y en que diferimos. Pues si se quiere entender que algo fuera de Dios pueda existir desde siempre, como si fuera posible que pudiera existir algo no hecho por Él, eso es un error abominable no sólo según la fe, sino también según los filósofos, quienes confiesan y prueban que todo lo que existe, sea de la manera que sea, no podría existir como no sea causado por quien posee el ser en su expresión suprema y más verdadera» ${ }^{21}$.

El problema no es si hay algo que no haya sido creado por Dios. Para Santo Tomás que el mundo haya sido creado por Dios no es sólo una verdad enseńada por la fe cristiana, sino también una verdad que la misma razón humana descubre.

Lo primero es indiscutible. Como ya se ha dicho, la Sagrada Escritura comienza indicando que el mundo fue creado por Dios (Gen, 1, 1). Está afirmación se repite muchas veces. Por ejemplo, se lee: «Porque el Señor lo ha hecho todo" (Ecl. 43, 33); "Al principio cimentaste la tierra, y el cielo es obra de tus manos» (Sal 101, 26); «Dios que hizo el cielo y la tierra, el mar y cuanto hay en él» (Sal 145, 5); «Yo soy el Señor y no hay otro, el que forma la luz y crea las tinieblas» (Is 45, 7); «El hizo la tierra con poder, cimentó el orbe con sabiduría, extendió los cielos con inteligencia» (Jer 10, 12); «Yo he creado la tierra, el ser humano y los animales que pueblan la tierra, usando mi gran poder y mi poderoso brazo» (Jer 27, 5); «Por medio de Él [el Verbo] se hizo todo, y sin Él no se hizo nada de cuanto se ha hecho» (Jn 1, 3); En Él [el Hijo] fueron creadas todas las cosas, celestes y terrestres, visibles e invisibles» $(\mathrm{Col} \mathrm{1,16).}$

21 Santo Tomás de Aquino (1953), p. 295; Michon (2004), p. 146. 
Igualmente la Iglesia ha proclamado la existencia de la creación desde el principio. Se encuentra ya afirmada en antiquísimos «símbolos de la fe», síntesis o resúmenes de lo creído y profesado. En el denominado «Símbolo de los Apóstoles», se dice: "Creo en Dios, Padre Todopoderoso, Creador del cielo y de la tierra» (Dz 7). En el llamado «Símbolo niceno-constantinopolitano, se profesa: «Creemos en un solo Dios, Padre omnipotente, creador del cielo y de la tierra, de todas las cosas visibles o invisibles» (Dz 86). También en el Concilio IV de Letrán, en el mismo texto citado, se dice de Dios: «creador de todas las cosas, de las visibles y de las invisibles, espirituales y corporales» ( $\mathrm{Dz} 428)$.

La afirmación de que el mundo procede de Dios por creación es muy importante para la filosofía, porque Santo Tomás no sólo considera que se puede demostrar con toda certeza la creación del mundo por Dios, sino que también es el primer principio de toda filosofía, acorde con la fe, o de las llamadas «filosofías cristianas». La tesis de que el mundo procede de Dios por creación significa que el mundo no es increado, ni tampoco que se ha autocreado. El mundo no es el absoluto, sino que ha sido creado por Dios. De ello, se sigue que la realidad creada no es suficiente y autónoma en su misma realidad, sino que entitativamente es dependiente de Dios.

Cuando Santo Tomás aborda el tema de la creación --principalmente en el Scriptum super quatuor libris Sententiarum Magistri Petri Lombardi (II Sent, d. 1), Summa contra gentiles (I, 32-38), Summa Theologiae (I, q. 44-46) y Quaestiones Disputatae de Potentia Dei (q. 3, a. 5) — trata dos grandes cuestiones: la naturaleza de la creación y el modo como se realiza. Sobre la primera, explica que el estudio de la naturaleza divina permite entender de alguna manera el hecho de la creación.

Se puede explicar la creación partiendo del constitutivo formal divino. Dios es el ser mismo y, por tanto, es ente por esencia. El ente que es su ser no puede ser más que uno, porque el ser de cada ente es único. Todos los demás entes tienen que ser entes por participación, porque su ser es un ser participado, no es el mismo ser, sino que lo poseen en parte. Además: «Lo que se predica esencialmente es causa de todo aquello que se predica por participación ${ }^{22}$. Luego, Dios es causa del ser de todos los demás entes.

22 SAnto Tomás de Aquino (2007), Summa contra gentiles, II, c. 15. 
El ente por esencia es causa de los entes participados, porque en éstos el ser no pertenece a su propia esencia, sino que, por tenerse o poseerse, es recibido, y, por tanto, donado por otro, que puede darlo, como es el ente que no lo tiene, sino que lo es. La acción de Dios, ente por esencia, produciendo todo el ser de todas las cosas, entes por participación, es lo que se llama creación.

El término crear, en sentido amplio, significa una clase de producción de un ente. Así, se dice, por ejemplo, que el escultor crea su obra. En sentido propio, crear consiste en hacer algo de la nada. Hacer algo de la nada es producir algo en el ser, pero sin materia o ningún sujeto previo $^{23}$.

Los entes creados, causas finitas, causan efectos, producen otros entes, pero este poder no es el de crear. En sentido propio, crear es hacer algo de la nada, es hacer que del no-ente aparezca todo el ser. En la producción de las criaturas, en cambio, se requiere siempre una materia o sujeto preexistente. Las criaturas, por consiguiente, no crean, porque producen una cosa de otra. En cambio, al crear, Dios no se sirve de nada previo. No se sirve de ninguna potencia, de ninguna materia previa, o de una capacidad de recibir alguna cosa por influencia de otra. Dios al crear no necesita nada más que su poder o potencia productiva. En la creación de Dios, se da una producción total ${ }^{24}$.

De esta argumentación, Santo Tomás infiere que «la creación es una acción propia de Dios»" ${ }^{25}$. Únicamente Dios puede crear, porque «crear es propio de un poder infinito» ${ }^{26}$ y como sólo lo tiene Dios: «la creación es acción propia de Dios y que sólo Él puede crear» ${ }^{27}$. Ninguna criatura puede crear, ni incluso recibir este poder de Dios, ni de forma natural ni milagrosa. Las criaturas no pueden participar del poder exclusivo de Dios de crear, ni como instrumento suyo, porque es imposible.

Santo Tomás da muchas razones sobre la imposibilidad de crear por la criatura. La que parece más patente es la siguiente: nadie más que Dios puede crear, ni como agente principal ni como instrumento, porque éste recibiría la acción

\footnotetext{
${ }^{23}$ Ibíd., II, c.16.

${ }^{24}$ Ibíd., II, c. 20.

25 Ibíd., II, c. 21.

26 Ibíd., II, c. 20.

${ }^{27}$ Ibíd., II, c. 21.
} 
de la causa primera, cosa que va contra la noción de creación, pues ésta nada presupone ${ }^{28}$.

Es quizá más importante esta segunda razón: todas las acciones de las criaturas implican movimiento o mutación. El «hacer» o «sacar» de la nada, en que consiste la creación, no implica una mutación entre dos términos positivos, como si la nada fuese una entidad. Si se dice que crear es «hacer»o «sacar» de la nada es porque el entendimiento humano en todas las acciones que conoce hay cambio, y, por ello, concibe igualmente la creación como una cierta mutación. Se la representa como si una misma cosa no existiese antes y sí después ${ }^{29}$, pero «toda creación excluye la sucesión» ${ }^{30}$. La creación, por consiguiente, no es ningún tipo de movimiento.

\section{Creación temporal y creación eterna}

Delimitado el sentido del problema de la eternidad del mundo, que implica, por tanto, que todo ha sido creado por Dios, en La eternidad del mundo Santo Tomás se ocupa de un aspecto de la segunda cuestión, el modo concreto con que Dios ha creado el mundo. El problema queda delimitado a: «Si se quiere entender que algo haya existido siempre puede ser hecho»" ${ }^{31}$. De manera que sobre el mundo creado son posibles dos hipótesis. La primera que ha tenido un principio en el tiempo o que la creación ha sido temporal. La segunda es que en la creación no ha habido comienzo temporal, o que el mundo creado es eterno.

En la segunda hipótesis, la de un mundo creado y eterno, hay que averiguar si es posible o no. «Si se dice que no puede ser hecho, sólo se puede entender de dos modos o habrá dos razones para ello; o a causa de la remoción de la potencia pasiva o por la repugnancia de conceptos".

La negación de la posibilidad de que un mundo creado sea eterno puede ser porque con ello se afirme la necesidad de una potencia pasiva previa al acto creador. «Del primer modo podría decirse, antes de que un ángel sea hecho, que "un ángel no puede ser hecho", pues no preexiste ninguna potencia pasiva a su existencia, ya que no es hecho de una materia previa; no obstante, Dios podía

\footnotetext{
28 Ibíd., II, c. 21.

${ }^{29}$ Ibíd., II, c. 17.

${ }^{30}$ Ibíd., II, c. 19.

31 Santo Tomás de Aquino (1953), p. 295; Michon (204), p. 146.
} 
hacer un ángel y podía también hacer que un ángel fuera hecho, puesto que lo hizo y fue hecho. Entendido así, hay que conceder sin más, de acuerdo con la fe, que una cosa causada no puede existir siempre, pues afirmarlo sería afirmar que la potencia pasiva ha existido siempre, lo que es herético. Sin embargo, de aquí no se sigue que Dios no pueda hacer que algo existente desde siempre sea hecho».

No se puede admitir la existencia previa de una potencia pasiva o sujeto en la creación de los espíritus o de los entes materiales, porque existirían antes de la creación por Dios. De esta negación no se sigue, no obstante, que no pueda darse una criatura eterna, porque queda por examinar si es válida la otra posible negación.

La negación de que sea posible que el mundo creado no sea temporal, sino eterno, es también porque parece que los conceptos de creación y eternidad impliquen una oposición contradictoria. «Del segundo modo se dice que algo no puede ser hecho por la repugnancia de conceptos, lo mismo que no puede ser hecho que la afirmación y la negación sean verdaderas a la vez; aunque algunos dicen que Dios puede hacer esto, otros, en cambio, dicen que ni Dios puede hacerlo, pues tal cosa no es nada. Es claro, no obstante, que no puede hacerlo, porque la afirmación una vez puesta se destruye a sí misma» ${ }^{32}$.

Santo Tomás siempre había enseñado que «todo lo que no implica contradicción está comprendido entre los posibles respecto a los cuales se llama omnipotente a Dios, y, en cambio, lo que la implica no está contenido bajo la omnipotencia divina, porque no puede tener razón de posible; por lo cual más exacto es decir que "no puede ser hecho" que no decir que "Dios no puede hacerlo"»33.

Sin embargo, nota a continuación en La eternidad del mundo: «Pero si se admite que Dios puede hacer una cosa así, esta posición no es herética, aunque creo que es falsa, como que el pasado no haya existido encierra en sí una contradicción; por eso San Agustín dice en el libro Contra Fausto: «Todo el que dice: "Si Dios es omnipotente, haga que las cosas que han sido hechas no lo hayan sido", no ve que está diciendo esto: "Si Dios es omnipotente, haga que las cosas que son verdaderas sean falsas en virtud de aquello por lo que son verdaderas"(XXVI, 5).

32 Santo Tomás de Aquino (1953), p. 296; Michon (204), pp. 147 s.

33 Santo Tomás de Aquino (1964), Summa Theologiae, I, q. 25, a. 3, in c. 
$\mathrm{Y}$, sin embargo, algunos grandes hombres dijeron piadosamente que Dios podía hacer que el pasado no fuera pasado, y no fue considerado herético» ${ }^{34}$.

De manera que Dios es omnipotente y puede hacerlo todo, pero no algo que no puede ser hecho. Como indica en el último texto citado de la Suma: «Y esto no se opone al dicho del ángel "Ningún verbo es imposible para Dios" (Lc $1,37)$, pues lo que implica contradicción no puede ser "verbo". Porque ningún entendimiento puede concebirlo» ${ }^{35}$. Lo imposible no pude realmente pensarse, ni verdaderamente decirlo.

No obstante, si alguien afirmara que Dios pudiera hacer algo contradictorio, no caería en herejía. El afirmar que Dios pueda hacer lo imposible no puede considerarse herético, porque no es algo que sea objeto de la infidelidad de la herejía. Santo Tomás en la misma Suma Teológica explica que «hablamos de la herejía en cuanto implica corrupción de la fe cristiana. Mas no hay corrupción de la fe cristiana si se tiene una opinión falsa en cosas que no pertenecen a la fe, como problemas de geometría o cosas semejantes, que son del todo extrańas a la fe». Este tipo de verdades serían de un sector de verdades, el de las que no pertenecen a la fe divina de ningún modo.

El ámbito de las verdades enseñadas por la Iglesia, en su misión de conservación y exposición de la Revelación o depósito de la fe, comprende otros dos sectores, indicados seguidamente por el Aquinate: «Hay, en cambio, herejía cuando se tiene una opinión falsa sobre algo que pertenece a la fe. Ahora bien, a la fe pertenece una verdad de dos maneras: una, directa y principal, como los artículos de la fe». Esta pertenencia es al sector de las verdades reveladas por Dios y definidas como tales por la Iglesia, es decir, al que forman los dogmas-artículos y los dogmas-conclusiones, explicados o explicitados por ella. Son verdades dogmáticas o verdades propuestas por la Iglesia como divinamente reveladas.

Añade a continuación Santo Tomás: «Otra, indirecta y secundaria, como las cosas que conllevan la corrupción de un artículo». Esta verdad pertenecería a un tercer sector de las verdades, que sin ser declaradas por la Iglesia como reveladas, es necesario que se afirme su verdad y certeza para mantener la verdad de algún dogma. Son las llamadas verdades católicas y definidas como tales, y, por tanto, como definitivas, al igual que las dogmáticas. Finalmente concluye: «Pues bien,

34 Santo Tomás de Aquino (1953), p. 296; Michon (204), pp. 148.

35 Santo Tomás de Aquino (1964), Summa Theologiae, I, q. 20, a. 3, in c. 
sobre ambos extremos (verdades de los dos últimos sectores) puede versar la herejía, lo mismo que la fe» ${ }^{36}$.

Como los dos tipos de verdades son objeto de fe, puede inferirse que el cambio o alteración de alguna de ellas es herejía. Sin embargo, como las verdades del segundo sector son de fe de manera "directa y principal», en su negación consiste principalmente la herejía. La corrupción de las verdades del tercer y último sector, por pertenecer a la fe de manera «indirecta y secundaria», da lugar a la herejía pero de manera también «indirecta y secundaria».

Esto parece ser lo que pensaba Santo Tomás sobre las verdades indirectas definidas por la Iglesia, porque en la respuesta a una de las objeciones que se presentan en este lugar precisa lo afirmado sobre la extensión de lo que puede ser herejía. «En ese sentido parece que se han dado disensiones entre algunos doctores [los Santos Padres], o sobre aspectos que de una manera u otra no afectan a la fe [el primer sector de verdades, señalado en el cuerpo del artículo], o también sobre aspectos que pertenecían a la fe, pero que aún no estaban definidos por la Iglesia [las conclusiones teológicas, que se derivan racionalmente o explicitan la Revelación, y las verdades filosóficas conexas a la fe]. Pero, una vez que quedaran definidos por la autoridad de la Iglesia universal [con lo cual pasarían al segundo sector, al de las verdades dogmáticas, o bien, al tercer y último sector, el de las verdades indirectas y secundarias de la fe], si alguien impugnara con pertinacia esa ordenación, sería tenido por hereje de manera directa y principal ante una verdad definida como dogmática o de manera indirecta y secundaria si lo es como definitiva ${ }^{37}$.

La negación de las verdades conexas a las verdades dogmáticas y declaradas como tales por la Iglesia y, por tanto, como definitivas, serán propiamente herejía cuando la misma Iglesia las defina ya como dogmáticas. Los que las niegan podrían incluso ser considerados como herejes, o como dice Santo Tomás que sostienen herejías impropiamente, porque lo hacen de manera «indirecta y secundaria». En cualquier caso, la Iglesia nunca los ha declarado herejes. Sólo se puede decir de ellos que no están en plena comunión con la Iglesia.

Sobre las otras verdades, que están conexas con la fe, pero que todavía no están definidas por la Iglesia como definitivas o católicas, o quizá no lo serán

36 Ibíd., II-II, q. 11, a. 2, in c.

37 Ibíd., II-II, q. 11, ad 3. 
nunca, con respecto a la fe, mientras no se pronuncie la Iglesia, pueden sostenerse. En realidad, en este sentido, pertenecen al primer sector de verdades, y la única calificación posible es la de verdaderas o falsas.

Teniendo en cuenta esta precisión, concluye en La eternidad del mundo: «Habrá que ver, pues, si hay repugnancia de conceptos en estos casos: que algo sea creado por Dios y que, sin embargo, haya existido siempre; y, haya lo que haya de verdadero en esto, que no será herético decir que Dios puede hacer que algo creado por Él haya existido siempre». Si los conceptos de criatura y eternidad no son incompatibles y se afirma que Dios puedo hacer algo creado eterno, no se estaría ante una herejía, porque la Iglesia, aunque ha definido como dogma el hecho de la creación temporal del mundo, no lo ha hecho con la posibilidad que Dios hubiera podido crearlo desde toda la eternidad. Incluso no sería herético si tal imposibilidad se considerase como conexa a la definición dogmática de la creación temporal. Se sostendría entones no una herejía, sino una falsedad.

En el caso de que no fuera incompatible criatura y eternidad, aunque sabemos por la fe que la creación fue temporal, habría que mantener, por tanto, la posibilidad de que podría haber sido eterna. Confiesa, por ello, seguidamente, en La eternidad del mundo: "Creo que si hubiera repugnancia de conceptos, sería falso, pero si no hay repugnancia de conceptos, no sólo no sería falso, sino tampoco imposible; decir otra cosa sería erróneo. En efecto, puesto que propio de la omnipotencia de Dios es exceder todo entendimiento y virtud, deroga expresamente la omnipotencia de Dios quien dice que en las criaturas puede entenderse algo que Dios no puede hacer; ni cabe el recurso a los pecados, pues éstos en cuanto tales no son nada ${ }^{38}$.

Si no se admitiera la posibilidad de ser realizado, si fueran compatibles los dos conceptos, un mundo creado eterno, supondría quitar poder a Dios, porque por su omnipotencia puede hacer todo lo que sea posible en la criatura. No puede objetarse que la causa del pecado, que está en las criaturas, no es Dios, y así no todo el poder estaría en Él, porque el pecado no es un ente, sino nada.

Santo Tomás explica, en otro lugar, que el pecado en sí mismo es una mera privación, una pura nada. «El pecado es un acto privado del orden debido, así como el robo o el adulterio es cierto acto desordenado; pues de este modo el pecado es nada, porque nada llegan a ser los hombres cuando pecan; ciertamente,

38 Santo Tomás de Aquino (1953), p. 297; Michon (204), pp. 148 s. 
no de tal modo que sean la nada misma, sino porque en cuanto pecan, se privan de algún bien; y la misma privación es un no ente en el sujeto. Y de modo semejante, el pecado es un acto privado del orden debido, y según la misma privación se dice nada» ${ }^{39}$.

El mal no es una adición a un bien amorfo, sino una resta o sustracción de bien. El comienzo del mal no está en Dios, sino en la criatura, porque se empieza con el impedimento a la ordenación al bien dada por Dios. Por tanto, la entidad física del mal procede de Dios. Sin embargo, Dios es solo causa primera del bien. Es la criatura la causa primera de todo mal. Recae sobre la causalidad divina solamente lo bueno, pero no lo malo.

En definitiva, concluye Santo Tomás, los primeros párrafos introductorios de La eternidad del mundo: "Toda la cuestión, pues, consiste en si ser creado por Dios en cuanto a toda la sustancia y no tener principio en el tiempo repugnan entre sí o no».

\section{Creación y temporalidad}

En la Suma contra los gentiles, Santo Tomás expone los argumentos racionales de los que sostenían, como los teólogos de la Facultad de Teología de la Universidad de París, que no es posible que el mundo haya sido creado desde la eternidad, porque hay razones que demuestran su imposibilidad. Concluían, por tanto, que en el concepto de creación es esencial que Dios haya originado lo creado en el tiempo. Con ello, además quedaba racionalmente probado que el mundo fue creado en el tiempo, tal como se afirmaba en la Biblia.

En La eternidad del mundo, Santo Tomás prueba indirectamente que creación y eternidad no "repugnan entre sí», mostrando que no es demostrable lo contrario, o que repugnan. Escribe por ello: «Que no repugnan se muestra así. Si repugnan, tiene que ser por una de estas dos razones o por las dos: o bien porque es necesario que la causa agente sea antes del tiempo; o bien porque es necesario que el no ser sea antes en el tiempo, por aquello que se dice de que lo creado por Dios es hecho de la nada» ${ }^{40}$.

39 Santo Tomás de Aquino (1965), Quaestiones disputatae de malo, q. 2, a. 1, ad. 4. Véase la traducción española en SANTo Tomás de Aquino (1997).

40 Santo Tomás de Aquino (1953), p. 298; Michon (2004), pp. 150. 
En la Suma contra los gentiles, empieza también tratando esta misma cuestión presentando los argumentos de «quienes aducen algunas razones para probar que el mundo no fue siempre», que intentan así demostrar racionalmente que, admitida la creación, no es posible sostener la eternidad del mundo. Santo Tomás presenta el primer argumento del modo siguiente: «Esta demostrado que Dios es causa de todas las cosas, y la causa debe preceder en duración a aquello que se hace por acción de la causa». Si Dios es causa de todas las cosas, y la causa debe preceder en duración a aquello que se hace por su acción, sólo Dios puede ser eterno. Por consiguiente, el mundo no es eterno, sino creado en el tiempo.

En este mismo lugar, Santo Tomás indica que no es concluyente necesariamente este primer argumento, Escribe, después de exponer todos los argumentos sobre la no compatibilidad: «Respecto a lo que se dice en primer lugar-que el agente necesariamente precede al efecto que es hecho por su operación-, esto es verdadero en los agentes que hacen algo por movimiento; porque el efecto no está sino en el término del movimiento, pues es necesario que se dé el agente ya cuando comienza el movimiento. Pero en los agentes que obran instantáneamente no es necesario esto, así como a la vez que el sol está asomando por el oriente ya ilumina nuestro hemisferio» " ${ }^{41}$. Sólo cuando hay movimiento en la operación, la causa necesariamente precede al efecto. Entonces la causa ya está cuando comienza el movimiento, pero el efecto no está sino al final del movimiento. En cambio, en la causa que obra instantáneamente, como es Dios al crear, no es necesaria la precedencia de la causa al efecto. Es posible, por tanto, mantener racionalmente que la creación no se ha dado en el tiempo.

La repuesta en La eternidad del mundo es parecida. Argumenta Santo Tomás: «Ninguna causa que produce su efecto de manera instantánea precede necesariamente en el tiempo a su efecto, pero Dios es una causa que no produce su efecto por movimiento sino instantáneamente, luego no es necesario que preceda en el tiempo a su efecto». Hay un tipo de causas que producen de manera instantáneamente el efecto, ya que no hay ningún progreso como en el tipo de causas que producen por movimiento. Así, por ejemplo, «el fuego, en el instante en que empieza a existir, calienta», o el sol al iluminar. En estos casos: «el término de la acción es simultáneo con lo hecho mismo; luego, no repugna al entendimiento que la causa que produce su efecto instantáneamente no preceda en el tiempo a lo causado por ella».

41 Santo Tomás de Aquino (2007), Summa contra gentiles, II, c. 38. 
En cambio, «repugna en las causas que producen sus efectos por movimiento, pues el principio del movimiento tiene que preceder a su fin». Observa, además - lo que sería el origen de este argumento contra la posibilidad de una creación eterna-, que: «Y estando los hombres acostumbrados a las producciones por movimiento, no captan con facilidad que la causa agente no precede en el tiempo a su efecto; de ahí viene que, desconociendo lo más se pronuncien a la ligera mirando a lo menos» ${ }^{42}$.

El segundo argumento de una oposición entre creado y eterno, que cita Santo Tomás, en la Suma contra los gentiles, es el siguiente: «Siendo todo el ser creado por Dios no se puede decir que haya sido hecho de otro ser, y así es forzoso decir que es hecho de la nada, y, por consiguiente, que tiene el ser después del no-ser ${ }^{43}$. El concepto de creación implica el tránsito de la nada al ser, y eso no sería posible si las cosas creadas hubieran existido desde siempre, desde toda la eternidad. Luego el mundo es temporal.

Así lo argumentaba San Buenaventura, al decir que si el mundo ha sido creado de la nada, tal como enseña la Escritura y se descubre por la razón, es que ha recibido la existencia después de no tenerla y, por consiguiente, que no puede siempre haber existido. Su razonamiento es el siguiente: «La producción de la nada supone el ser después del no ser por parte del producido e inmensidad de fuerza productora por parte del principio, siendo esto propio de sólo Dios es necesario que el mundo sea producido en el tiempo por la misma virtud infinita, obrando por sí misma e inmediatamente» ${ }^{44}$.

Considera San Buenaventura que: «Sostener que el mundo es eterno, o producido en la eternidad, afirmando a la vez que todas las cosas fueron producidas de la nada, va contra toda verdad y razón (...) está en tal oposición con la razón, que pienso que ningún filósofo, por poco ingenio que tuviese, haya sostenido. $Y$ es que eso encierra en sí una manifiesta contradicción» ${ }^{45}$. En cambio, afirmar que el mundo es eterno, si no se conoce que el mundo es creado, y se cree que se ha hecho de la eternidad de la materia "parece razonable e inteligible».

42 Santo Tomás de Aquino (1953), p. 299; Michon (2004), pp 151 s..

43 Santo Tomás de Aquino (2007), Summa contra gentiles, II, c. 38.

44 San Buenaventura, Breviloquium, II, c. 1, n. 3, en Ed. Quaracchi, vol V (1891), p. 219b, y en San Buenaventura (1945-1968), vol. 1, pp. 155-539, p. 243.

45 San Buenaventura, Commentaria in quatuor libros Sententiarum Magistri Petri Lombardi, II, d. 1, p. I, a. 2, q. 2, concl. en ed. Quaracchi, vol II (1985), p. 29a. 
La respuesta de Santo Tomás al segundo argumento, en la Suma contra los gentiles, es la siguiente: «Lo que se dice en segundo lugar no concluye. Lo contradictorio de «ser hecho algo de algo» — que debe darse, si no se da esto- es «ser hecho no de algo"; mas no lo es el ser hecho "de nada", de no tomarlo en el primer sentido; por lo que no se puede concluir que sea hecho después del no-ser ${ }^{46}$. Debe recordarse que la creación es un acto instantáneo e indivisible. No hay movimiento, tránsito de un modo de ser a otro, ni, por ello, requiere tiempo alguno. La creación es una aparición de un ser, que no viene de ningún otro, ni de ninguna parte. La nada no existe y, no es propiamente, por tanto, punto de partida de la creación. No es necesario, por consiguiente, concluir que el mundo es temporal.

En La eternidad del mundo, después de apoyar su respuesta al primer argumento con otras respuestas a cuestiones relacionadas con el mismo, presenta así el segundo: "Queda ahora por ver si repugna al entendimiento que lo que ha sido hecho nunca haya estado sin existir, dado que es necesario que su no existencia le haya precedido en el tiempo, por cuanto se dice que ha sido hecho de la nada».

Nota Santo Tomás que puede afirmarse que algo creado sea eterno: «Pero que esto no repugna lo más mínimo se ve por lo que dice Anselmo en el Monologio capítulo 8 , donde expone cómo se dice que la creatura ha sido hecha de la nada: «Empleamos — dice— la tercera interpretación cuando decimos que algo ha sido hecho de la nada, entendiendo que ha sido verdaderamente hecho, pero que no hay nada de lo cual ha sido hecho. Así se dice de un hombre oprimido por la tristeza sin causa. Si se entiende en este sentido lo que hemos dicho anteriormente, a saber, que, excepto la esencia suprema, todo lo que viene de ella ha sido hecho de la nada, es decir, no ha sido hecho de algo (...) no se encontrará ninguna contradicción». Es claro, por tanto, de acuerdo con esta exposición, que lo hecho no se pone en orden ninguno a la nada, como si fuera necesario que lo que ha sido hecho hubiera sido nada y luego fuera algo».

Cuando se dice «hecho de la nada», puede parecer que la preposición «de» implique que haya precedido la no existencia de lo creado a la existencia de lo creado, y, por tanto, que la nada hay precedido al ser. Lo que realmente se significa con esta expresión es que algo ha sido hecho, pero no de algo.

46 Santo Tomás de Aquino (2007), Summa contra gentiles, II, c. 38. 
No obstante, «supóngase que se sigue afirmando el orden a la nada denotado en la preposición, de modo que el sentido sea que la criatura ha sido hecha después de la nada. Este término «después» denota un orden sin más. Pero el orden es múltiple, a saber, de tiempo y de naturaleza». En este último sentido: «Basta con que la nada sea anterior por naturaleza al ente. En efecto, lo que le conviene a una cosa por sí misma está en ella naturalmente antes que lo que únicamente tiene de otro; pero la creatura tiene el ser únicamente de otro; dejada a sí misma, considerada en sí misma, no es nada; luego la nada le es naturalmente anterior que el ser».

No hay ningún orden temporal entre la nada y el existir, como si primero hubiese la nada y después la existencia. No puede pensarse que la nada esté en el tiempo, en un tiempo que sería previo al de la existencia. Parece que se piensa así por influencia de la imaginación. En cambio, sí es posible entender que hay un orden de naturaleza, en cuanto que la nada es lo que por si mismos les es propio a los existentes, por recibir la existencia de otro, y si no la recibieran dejarían de existir y serían nada. Puede decirse, por tanto, que a los entes creados les es más natural la nada que la existencia.

Precisa Santo Tomás seguidamente que, con ello, no se sostiene que sea «necesario que la nada y el ser existan a la vez: no se afirma, en efecto, que si la creatura existió siempre, fue nada en algún tiempo, sino que se afirma que su naturaleza sería tal que, si se la dejase a sí misma, sería nada ${ }^{47}$.

Al decirse que la nada no es anterior a la existencia, no puede pensarse que la nada y la existencia han existido juntas en momento alguno. De manera que si lo creado fuese eterno no habría existido tampoco nunca como nada, pero el orden de la naturaleza supone que lo existente, aunque fuese eterno, si se le dejase a sí mismo, perdería la existencia y sería entonces nada.

\section{Temporalidad del mundo}

Después de estos dos argumentos racionales, Santo Tomás, en este mismo opúsculo, para mostrar finalmente que «cuando se dice que algo ha sido hecho por Dios y que nunca estuvo sin existir, no hay repugnancia conceptual $»^{48}$, utiliza argumentos de autoridad, entre ellos el que se contiene en el siguiente ejemplo

47 Santo Tomás de Aquino (1953), p. 303; Michon (2004), p. 156.

48 Ibíd., p. 306; Мichon (2004), p. 157. 
de San Agustín: «Si el pie estuviese desde toda la eternidad sobre el polvo, habría tenido siempre bajo sí su huella, la cual nadie dudaría haber sido estampada por el que allí pisara, así también el mundo ha existido siempre, porque existe siempre el que lo ha hecho ${ }^{49}$. Aunque el mundo fuese eterno, continuaría dependiendo absolutamente de su causa. Siempre depende de ella en el tiempo o en la eternidad.

Comentando, Santo Tomás, en la Suma teológica este mismo pasaje de San Agustín, escribe: «Para entender este razonamiento se debe observar que la causa eficiente que obra con movimiento, por necesidad precede temporalmente a su efecto; porque el efecto no existe hasta el término de la acción, de la cual necesariamente es principio el agente. Pero, si la acción es instantánea y no sucesiva, no es necesario que el agente preceda en duración a aquello que hace, como lo vemos en la iluminación. Por lo cual dicen que no es necesario que Dios preceda al mundo en duración aunque sea causa activa del mismo; porque la creación, mediante la cual produjo Dios el mundo, no es una mutación sucesiva ${ }^{50}$.

En la Suma contra los gentiles, Santo Tomás presenta también tres argumentos, que da San Buenaventura para demostrar racionalmente la temporalidad del mundo. El primero es el siguiente: "Como el infinito no es intraspasable, si el mundo hubiese sido siempre tendríamos que habrían transcurrido ya infinitos instantes, porque lo que es pretérito ya transcurrió; si, pues, el mundo fue siempre, han pasado infinitos días o circunvoluciones solares $»^{51}$. Los cuerpos celestes, si el mundo no tuvo principio, deben haber dado infinitas revoluciones, y, con ello, nunca habrían podido encontrarse en el presente, porque no se puede recorrer una serie que es infinita ${ }^{52}$.

Santo Tomás replica que «lo que se afirma $[. .$.$] no tiene fuerza. Pues aunque$ no se dé el infinito a la vez en acto, puede, sin embargo, darse sucesivamente; porque así, todo infinito dado es finito. Y, por tanto, cualquier circunvolución de las precedentes pudo pasar porque fue finita. Ahora bien, si el mundo hubiese sido siempre, entre todas ellas a la vez no se habría podido señalar una primera, y así, tampoco el tránsito, que siempre exige dos extremos ${ }^{53}$. Argumenta, por

\footnotetext{
49 San Agustín, De civitate Dei, X 31, en San Agustín (1977).

50 Santo Tomás de Aquino (1964), Summa theologiae, I, q. 46, a. 2, in c.

51 Santo Tomás de Aquino (2007), Summa contra gentiles. II, c. 38.

52 Cf. San Buenaventura, Commentaria in quatuor libros Sententiarum Magistri Petri Lombardi, Sent., II, d. 1, p. 1, a. 1, q. 2., en San Buenaventura (1945-1968), vol. IV.

53 Santo Tomás de Aquino (2007), Summa contra gentiles. II, c. 38.
} 
tanto, con la distinción entre el infinito potencial, como la serie de los números naturales, y el infinito en acto. En este último caso, no habría movimiento. El infinito, "aquello que no tiene límites» ${ }^{54}$, puede tomarse en sentido absoluto, como lo que no tiene límites ni en acto ni en potencia; y también en sentido relativo, cuando tiene límites en acto. La infinitud absoluta o actual es propia y exclusiva de Dios. Los otros seres, aunque sean indefinidos o no tengan límites en potencia, siempre son limitados o finitos en acto $^{55}$.

En un segundo argumento de San Buenaventura se continúa el anterior notando que si el mundo no hubiera tenido principio temporal, en el presente ya habría pasado un tiempo infinito. Además, cada día que pasa supone que se añade una unidad, pero sería imposible, porque no se puede ańadir nada a lo que es infinito ${ }^{56}$. Santo Tomás lo sintetiza así: «Se sigue además que, al añadir cada día más a los días y circunvoluciones pretéritas, se añadiría algo al infinito».

Responde al mismo indicando: «Lo que se propone (...) carece de consistencia. Porque nada impide añadir algo al infinito por la parte que es finito. Pues al afirmar un tiempo eterno, consiguientemente es infinito por la parte anterior, pero finito por la parte posterior, porque el presente es el término del pretérito» ${ }^{57}$. El argumento sólo tendría sentido si se afirmará que el mundo es infinito en los dos sentidos.

San Buenaventura ofrece un tercer argumento contra la eternidad del mundo. Si el mundo fuera eterno, nota que el ser humano hubiese existido siempre y como consecuencia, habría un número infinito de almas inmortales. Entonces existirían a la vez un número infinito de almas, lo que parece imposible ${ }^{58}$, o como al sintetizarlo dice el Aquinate: «se dará el infinito en acto, es a saber, las almas inmortales de infinitos hombre pretéritos».

Replica Santo Tomás, en este mismo capítulo de la Suma contra los gentiles: «Lo que se objeta (...), sobre las almas ofrece más dificultad. Sin embargo, la razón no es muy útil, porque supone muchas cosas. Algunos de los que afirmaban la eternidad del mundo afirmaron también que las almas humanas no se

54 Santo Tomás de Aquino (1964), Summa theológiae, I, q. 7, a. 1, in c.

55 Ibíd., I, q. 7, a. 2, in c.

56 Cf. San Buenaventura, Commentaria in quatuor libros Sententiarum Magistri Petri Lombardi, Sent., II, d. 1, p. 1, a. 1, q. 2, en San Buenaventura (1945-1968), vol. IV.

57 Santo Tomás de Aquino (2007), Summa contra gentiles. II, c. 38.

58 Cf. San Buenaventura, Commentaria in quatuor libros Sententiarum Magistri Petri Lombardi, Sent., II, d. 1, p. 1, a. 1, q. 2, en SAn Buenaventura (1945-1968), vol. IV. 
darían después del cuerpo. Otros, que de todas las almas no permanece sino el entendimiento separado; el agente, según unos; el posible, según otros. Otros defendieron el retorno de las almas, diciendo que después de algunos siglos las almas humanas tornan a los cuerpos. Hay quienes no tienen inconveniente en que se den algunos infinitos en acto, en aquellas cosas que no guardan orden entre sí» ${ }^{59}$.

En esta misma obra, más adelante, indica sobre esta última posibilidad: «Otros, para evitar todo lo anterior, dijeron que no hay inconveniente para que existan actualmente infinitas almas separadas, porque el ser infinito en acto en aquellos que no guardan orden entre sí es ser infinito accidentalmente; y no tuvieron inconveniente en admitirlo. Esta opinión es de Avicena y Algazel» ${ }^{60}$.

Sin embargo, en la Suma Teológica, Santo Tomás niega que se dé esta posibilidad. Al tratar la cuestión de si es «posible la existencia de una multitud real infinita", después de examinar la posición citada de Avicena y Algazel, concluye: «Es imposible que exista una multitud infinita en acto, aunque sea accidental» ${ }^{61}$.

La respuesta del Aquinate a este tercer argumento racional con el que San Buenaventura creía probar la no-eternidad del mundo, es, en definitiva, que Dios pudo crear el mundo en la eternidad y que, sin embargo, hubiese podido crear al hombre y, con ello, su alma, en un cierto momento del tiempo.

También en la Suma Teológica indica, además, que no sólo no es posible demostrar la no-eternidad del mundo, como pretenden San Buenaventura y otros, sino que, con la afirmación de la eternidad del universo, tampoco se concede al mundo un claro atributo de Dios, como es la eternidad, fundada en su inmutabilidad omnímoda: «Aunque hubiese existido el mundo siempre, no por eso sería igual a Dios en cuanto a la eternidad, como dice Boecio, en La consolación $(5,6)$; porque la existencia divina es toda a un mismo tiempo, mientras que la del mundo siempre sería sucesiva» ${ }^{62}$.

La eternidad no es sólo una duración o permanencia en el ser que carece de principio y de fin, sino también ausencia de sucesión o cambio. Como Boecio la

59 Santo Tomás de Aquino (2007), Summa contra gentiles. II, c. 38.

${ }^{60}$ Ibíd., II, c. 81, ad 3. Cf. Avicena, Metaphysica, trat. 6, c. 2; trat 8, c. 1; y Algazel, Philosophia, l. I, trat. 1, c. 2.

${ }^{61}$ Santo Tomás de Aquino (1964), Summa theologiae, I, q. 7, a. 4, in c.

${ }^{62}$ Ibid., I q. 46 a. 2 ad 5. 
había definido, en el lugar citado, la eternidad es «la posesión total, simultánea y perfecta de una vida interminable» ${ }^{63}$. Sólo Dios es, en sentido estricto, eterno.

En conclusión, para Santo Tomás la cuestión de la temporalidad o eternidad del mundo en sentido amplio es una cuestión abierta para la filosofía. Lo que no ocurre con el hecho de que las cosas han sido creadas, conclusión racional o filosófica. Si el mundo ha existido siempre o comenzó en algún momento temporal no tiene respuesta para la filosofía. Sin embargo, la fe cierra la cuestión, porque enseńa que el mundo tuvo un origen en el tiempo, que todo lo creado ha comenzado a existir.

Al tratar esta cuestión, en la Suma teológica, Santo Tomás concluye: "Que el mundo no ha existido siempre, lo sabemos sólo por la fe, y no puede demostrarse apodícticamente; lo mismo que hemos dicho anteriormente sobre el conocimiento del misterio de la Santísima Trinidad». La cuestión es, para la razón humana, un misterio, como lo es la Trinidad de Dios.

No sólo no se puede demostrar la no eternidad del mundo, sino consecuentemente tampoco de manera directa su temporalidad. «La razón de esto — señala el Aquinate- es porque el comienzo del mundo no puede tener una demostración tomada de la naturaleza misma del mundo». No es posible por dos motivos.

El primero es el siguiente: «El principio de la demostración es la definición o esencia misma de la cosa demostrada. Cualquier cosa, considerada en cuanto a su esencia o especie, prescinde del tiempo y del espacio; por lo cual se dice que: "los universales son en todo lugar y tiempo». Luego no puede demostrarse que el hombre, o el cielo, o la piedra no hayan existido siempre».

El segundo motivo es porque «tampoco se puede demostrar por parte de la causa eficiente, por ser ésta un agente que obra a voluntad. La voluntad de Dios es ciertamente inescrutable para la razón humana, a no ser sobre aquellas cosas que es absolutamente necesario que Dios las quiera, y Dios no quiere de este modo nada de cuanto se refiere a las criaturas».

No hay respuesta decisiva a la pregunta sobre la eternidad o temporalidad del mundo porque depende de la voluntad de Dios, que no puede ser conocida

${ }^{63}$ Boecio, De consolatione Philosophiae Libri quinque, V, 6; en Migne (1875), Patrologia latina, vol. 63, col. 480-524. Cf. Boecio (1999), p. 182. 
por la razón humana. «Puede, sin embargo, la voluntad divina manifestarse al hombre mediante la revelación, en la cual se funda nuestra fe. Por consiguiente, que el mundo ha comenzado a existir, es creíble, pero no es demostrable ni objeto de la ciencia humana».

No hay, por consiguiente, una «doble verdad» en esta cuestión. Por un lado, desde la fe se cree que Dios creó el universo de la nada desde el principio del tiempo, en lo que los profesores de la Facultad de Artes y los de la Teología, están de acuerdo. Por otro, en el ámbito filosófico, es necesario mantener la suspensión del juicio.

Santo Tomás coincide, por tanto, con Boecio de Dacia en que no puede demostrarse la temporalidad del mundo, pero diverge dell filósofo en cuanto sostiene que tampoco puede demostrarse su eternidad, ni de manera no absoluta o probable, ya que la temporalidad tendría idéntica posibilidad. En esta cuestión, no puede darse ninguna respuesta.

Frente a San Buenaventura y a los teólogos de la Facultad de Filosofía, afirma Santo Tomás que la temporalidad de la creación es sólo artículo de fe, porque si se intentara probar no se darían razones concluyentes. Además, les advierte a éstos que el no admitirlo es perjudicial para la misma fe. «Y esto conviene tenerlo muy en cuenta, no sea que, presumiendo alguno demostrar las cosas que son de fe, alegue razones no convincentes, con lo cual dé a los no creyentes ocasión de irrisión, juzgando ellos que por tales razones asentimos nosotros a las cosas que son de fe» ${ }^{64}$.

\section{El problema fundamental}

Las diferentes soluciones al problema de la eternidad del mundo, dependen en último término de la posición que se tenga sobre si la razón y la fe se relacionan y en caso afirmativo del modo como lo hacen. Se advierte claramente en la solución de Boecio de Dacia, quien la explícita al dar su solución. Para Santo Tomás, a diferencia de este último, la fe es una actividad del pensamiento. El creer no es un acto irracional. La fe tiene una racionalidad propia. Dos razones lo confirman. La primera, por ser un acto de la inteligencia humana: «Creer es inmediatamente acto del entendimiento, porque su objeto es la verdad, que

${ }^{64}$ Santo Tomás de Aquino (1964), Summa Theologiae, I, q. 46 a. 2 in c. 
propiamente pertenece a éste; en consecuencia, es necesario que la fe, principio propio de este acto, esté en el entendimiento como en sujeto» ${ }^{65}$.

Con el acto de fe, la razón del hombre no queda rebajada ni anulada. Con la aceptación de su presupuesto filosófico o racional —la veracidad Dios, cuya existencia y atributo también demuestra la metafísica - la inteligencia humana realiza un acto propiamente humano.

La segunda razón, que prueba que la fe tiene una racionalidad o inteligibilidad propia, es porque es un acto de pensar, que constituye un pensamiento o juicio. Como cualquier otro acto implica una indagación sobre su contenido objetivo y un asentimiento o certeza, el aspecto sujetivo de todo juicio, que consiste en la adhesión individual a su verdad.

Afirma Santa Tomás que «la fe media entre la opinión y la ciencia» ${ }^{66}$. Por una parte, porque, al igual que en la opinión, en la fe no hay un conocimiento claro de lo conocido, aunque en la primera eso ocurre como resultado de una indagación imperfecta, mientras que en la fe, en cambio, no hay indagación personal de ningún tipo. Por otra, hay una coincidencia de la fe con la ciencia en la certeza, porque ambas son perfectas. Sin embargo, la certeza de la fe no la proporciona la clara visión del objeto intelectual, como en el saber científico, sino la presión de la voluntad, movida por la gracia de Dios, al entendimiento.

Además, en la Revelación se encuentran también verdades racionales y filosóficas. Afirma también Santo Tomás que fue conveniente la revelación de estas verdades, que sin ella sólo poseerían unos pocos hombres, después de mucho tiempo y con gran incertidumbre. Fue precisa la revelación de estas verdades racionales, en sí mismas asequibles al hombre, por vía de fe, para que así pudieran llegar a todos los hombres de manera inmediata y con una perfecta certeza.

Su necesidad se explica porque no era suficiente la revelación de las verdades sobrenaturales sin estas verdades naturales, que sólo parecen tener una utilidad filosófica. Las verdades naturales reveladas no sólo tienen un interés filosófico, sino también para la fe. El Aquinate las considera "preámbulos de la fe», porque son la base racional inmediata a los contenidos exclusivos de la fe, aquellos que no son cognoscibles por la razón natural.

${ }^{65}$ Ibid., II-II q. 4 a. 2 in c.

${ }^{66}$ Santo Tomás, Summa Theologiae, II-II q. 1 a. 5 ob. 4. 
Las verdades, o preámbulos a los artículos de la fe, no son a la vez de fe o sobrenaturales y asequibles o naturales a la razón humana, porque sería contradictorio. Estas verdades para unos son naturales o racionales, porque en sí mismas son demostrables por las razón humana, aunque es difícil sin dudas ni errores. Otros, gracias a la revelación, las aceptan como de fe, o con una racionalidad que sobrepasa la capacidad humana. De este modo todos los hombres pueden conocerlas, unos como creídas y otros como comprendidas por su razón.

Estas observaciones de Santo Tomás justifican la definición agustiniana de fe. Afirmaba San Agustín que "creer es pensar con asentimiento»" ${ }^{67}$. Lo hacía desde una concepción amplia y unitaria de sabiduría cristiana, que englobaba la religión y la filosofía, sin identificarlas ni relacionarlas. Aunque afirmaba la superioridad de la fe sobre la razón, no había trazado los límites entre lo natural y lo sobrenatural. En cambio, Santo Tomás desde estos presupuestos estableció una neta distinción entre razón y fe, entre la Filosofía y la Teología.

Sin embargo, esta distinción y la primacía de la fe sobre la razón no implican un conflicto entre ambas. La fe esta por encima de la razón y, sin embargo, no es posible una verdadera disensión entre ellas. Admitirla supondría atentar contra la unidad de la verdad. La revelación y la razón humana tienen un mismo origen: Dios, que no puede contradecirse. El mismo Dios, que mueve a la voluntad humana en el acto de fe y que revela los misterios objeto de la fe, es quien ha creado el espíritu humano con la facultad de la razón. Dios, que no es contradictorio, no se niega a sí mismo.

Si, en algún caso, se presenta una contradicción entre la razón y la fe es únicamente aparente. La supuesta contradicción puede haber sido producida por la falsedad de las tesis racionales, que se han tomado, sin serlo, por verdaderas; o bien, porque los contenidos de la fe no han sido bien entendidos o no se han expuesto tal como la Iglesia los enseña.

Del motivo de la imposibilidad de una doble verdad, o de la oposición contradictoria entre la fe y la razón, del que Dios sea autor y origen de toda verdad, se sigue una importante consecuencia, opuesta a la posición de Boecio de Dacia: la fe y la razón se ayudan mutuamente. La razón, que es utilizada por la ciencia teológica en sus investigaciones, es para ella un instrumento necesario; y también la razón muestra los fundamentos racionales del hecho de la revelación. A

${ }^{67}$ San Agustín, De praedestinatione sanctorum, c. 2; en San Agustín (1949), vol. VI. 
su vez, la fe ayuda a la razón librándole de muchos de sus errores; y asimismo proporcionándole conocimientos racionales de ámbito filosófico, lo que Santo Tomás denomina preámbulos de la fe.

La Teología, por consiguiente, no se opone a la Filosofía en general ni a la Filosofía de la naturaleza en particular, porque ambas, al igual que los saberes filosóficos, tienen el último origen en Dios y pueden ser el punto de partida para llegar hasta Él. La Teología debe reconocer que las ciencias filosóficas gozan de una autonomía propia. Su ámbito, sus principios y sus métodos son exclusivos, pero la religión les advierte cuando traspasan sus propios límites. Puede decirse que, con ello, vela por su justa libertad.

Con esta distinción y asociación entre la razón y la fe, queda establecida una relación armónica entre ellas, que respeta la autonomía, las competencias y el valor de ambas. Por ello, la Filosofía y la Teología deben colaborar en su común búsqueda de la verdad, aunque por los caminos distintos, pero concordes, de la razón y de la fe, ayudándose mutuamente. No es posible la absoluta independencia de la Teología y de la Filosofía. Para Santo Tomás, ello terminaría en la negación de ambas.

La razón y la fe no sólo no se oponen y se ayudan mutuamente, sino que la primera conduce a la segunda. Por ello, el estudio de las criaturas contribuye a la comprensión de la fe cristiana. Para Santo Tomás, es necesario su conocimiento para desechar los errores sobre Dios, pues los errores sobre las criaturas alejan del verdadero conocimiento de Dios y también, por ello, de las verdades de la fe. Las concepciones equivocadas de las criaturas llevan a una doctrina también falsa sobre Dios y, con ella, ya no es posible aceptar la fe cristiana, porque no es posible que la falsedad sea sujeto de la verdad. Todo error impide o aparta de la fe ${ }^{68}$.

La fe, sin embargo, es un conocimiento racional superior al conocimiento corriente y al filosófico, pero no hay que olvidar nunca su distinción. Por una parte, en la fe el entendimiento no comprende aquello a que asiente creyendo; por otra, que el entendimiento asiente porque quiere, movido por un auxilio especial de Dios, y no forzado por la evidencia misma de la verdad ${ }^{69}$.

68 SAnto Tomás, Summa contra gentes, II, c. 3.

${ }^{69}$ Cf. Ibíd., III, c, 40. 


\section{Bibliografía}

San Agustín (1995). Obras completas de San Agustín, vol. VI, De predistiantione sanctórum (Trad. Emiliano Lópe),VII, Sermones (1. ${ }^{\circ}$, Sobre el Antiguo Testamento, (Trad. y notas de Pío de Luis) y vols. XVI-XVII, De civitate Dei (trad, S. Santamarta y M. Fuertes), Madrid, BAC.

BazÁn, B.C. (2002), "Boethius of Dacia», en J. J. E. Gracia-T. B. Noone (eds.), A Companion to Philosophy in the Middle Ages, Blackwell Publishing, Malden-OxfordMelbourne-Berlin,pp. 228-229

Boecio (1999). Boecio, La consolación de la Filosofía, traducción de P. Rodríguez Santidrián, Madrid, Alianza.

Boecio de Dacia (1964). Boethius de Dacia, Tractatus de aeternitate mundi, edición crítica de Géza Sajó, Col. "Fuentes y Estudios sobre la Historia de la Filosofía», Berlin, W. de Gruyter.

San Buenaventura (1945). Obras de San Buenaventura, edición bilingüe, Madrid, BAC, 6 vols.

- (1882-1887). San buenaventura, Opera Omnia, edición. de Quaracchi, PP. Collegii S. Buenaventurae, P.B. Portogruar, Quaracchi, Ad Claras Aquas, 10 vols.

Denifle-Chatelain (1964). Henri Denifle- E. Chatelain, eds., Chartularium universitatis Parisiensis, Bruselas, Culture et Civilisation.

Denzinger (1963). Heinrich Denzinger, El magisterio de la Iglesia, Manual de los símbolos, definiciones y declaraciones de la Iglesia en materia de fe costumbre, traducción de D. Ruíz Bueno, Barcelona, Herder.

Ferrua (1968). A. Ferrua, OP, S. Thomae Aquinatis fontes praecipuae, Edizioni Domenicane, Alba.

Gilson (1965). Étienne Gilson, La filosofía en la Edad Media, Madrid, Editorial Gredos.

Le Brun-Gouanvic (1996). Le Brun-Gouanvic, "Ystoria sancti Thome de Aquino» de Guillaume de Tocco (1323), edición crítica, con texto en latín y estudio preliminar en francés, Studies and Texts, 127; Pontifical Institute of Medieval Studies, Toronto.

Michon (2004). Cyrille Michon, Thomas d'Aquin et la controverse sur 'L'Éternité du monde, París, GF Flammarion.

Migne, J.P. (1857). Patrologiae Graecae, Paris, Vrayet de Sourcy, vols. 3, 7, 7b, 11, 26, $29 \mathrm{~b}$.

- (1875). Patrologiae Latinae, Paris, Vrayet de Sourcy, vol. 63. 
Santo Tomás de Aquino (1953). Sto. Tomás de Aquino, Opuscula philosophica, edición Spiazzi. R.M. O.P., Torino, Marietti Editore.

- (1964). Sto. Tomás de Aquino, Summa Theologiae, edición bilingüe, Madrid, BAC.

- (1965). Sto. Tomás de Aquino, Quaestiones Disputatae De Malo, Turín-Roma, Marietti Editore.

- (1997). Sto. Tomás de Aquino, Cuestiones disputadas sobre el mal, edición de E. Téllez, Pamplona, EUNSA.

- (2007). Sto. Tomás de Aquino, Suma contra gentiles, edición bilingüe, Madrid, BAC, 2 vols.

Schneider, J. H. J. (1999). "The eternity of the world: Thomas Aquinas and Boethius of Dacia", Archives d'histoire doctrinale et littéraire du Moyen-âge (París), 66 (1999) 121-141.

Recibido: $17 / 12 / 2013$

Aceptado: 28/02/2014 
